DOI: https://doi.org/10.47405/mjssh.v6i5.782

\begin{tabular}{|c|c|}
\hline & Malaysian Journal of Social Sciences and Humanities (MJSSH) \\
\hline Malaysian Journal of & Volume 6, Issue 5, May 2021 \\
\hline $\begin{array}{l}\text { Hunantues } \\
\text { (MM-.sSH) }\end{array}$ & e-ISSN : 2504-8562 \\
\hline$=-$ & $\begin{array}{l}\text { Journal home page: } \\
\text { www.msocialsciences.com }\end{array}$ \\
\hline
\end{tabular}

\title{
Cabaran Perkhidmatan Penghantaran Makanan Semasa Pandemik COVID-19
}

\author{
Nur Aqilah Mohd Rasidi1, Nurul Fatihah Ismail1, Putri Humira Yap Abu Bakar Yap¹, \\ Mohamad Izzuan Mohd Ishar1 \\ 1Sekolah Pendidikan, Fakulti Sains Sosial dan Kemanusiaan, Universiti Teknologi Malaysia (UTM)
}

Correspondence: Puteri Humira Yap Abu Bakar Yap (yap1998@graduate.utm.com)

\begin{abstract}
Abstrak
Pendapatan menurun kesan serangan korona virus (COVID-19) di seluruh negara sehingga isu pengangguran meningkat dalam kadar yang tinggi akibat keadaan ekonomi yang tergugat saban hari. Walaupun keadaan ekonomi tidak stabil, masyarakat yang sejajar dengan perkembangan globalisasi ini bijak mengambil peluang untuk mewujudkan langkah baru dalam kehidupan. Antara isu yang diberi perhatian dalam kajian ini adalah cara masyarakat mengambil peluang untuk bangkit semula dalam meningkatkan pendapatan semasa berlakunya pandemik korona virus yang telah banyak memberi kesan dalam taraf hidup. Sehubungan itu, kajian ini bertujuan untuk mengkaji cabaran yang dihadapi oleh pekerja penghantar makanan sepanjang perintah kawalan berjalan di seluruh negara ini. Kajian ini dijalankan melalui pengedaran borang soal selidik secara atas talian kepada masyarakat setempat bagi mendapatkan data yang lebih lengkap. Hasil dapatan kajian yang ditunjukkan melalui graf membuktikan waktu pandemik Covid-19 ini mempengaruhi pekerjaan sebagai penghantar makanan dengan wujudnya pelbagai cabaran semasa penghantaran dijalankan.
\end{abstract}

Kata kunci: COVID-19, penghantar makanan, cabaran

\section{Food Delivery Service Challenges During Pandemic COVID-19}

\begin{abstract}
Due to the viral corona attack (COVID-19), income has fallen across the country, and even the daily economic crisis has caused unemployment to increase at a very high rate. Despite the unstable economic situation, with the development of globalization, society wisely seized opportunities to create new life steps. One of the issues that received attention in this study is that during the coronavirus pandemic, society took advantage of opportunities to increase income again, which had a major impact on living standards. Therefore, this study aims to examine the challenges faced by food delivery workers in all control orders executed across the country. This research was conducted by distributing questionnaires to local communities online to obtain more complete data. The research results shown in the graph prove that the time of the COVID-19 pandemic has affected the job as a food delivery person, and there are various challenges in the food delivery process.
\end{abstract}

Keywords: COVID-19, food delivery, challenges 


\section{Pengenalan}

Pandemik COVID-19, juga dikenali sebagai pandemik koronavirus atau wabak koronavirus ialah pandemik penyakit koronavirus 2019 yang sedang berlaku secara global berpunca daripada koronavirus sindrom pernafasan akut teruk 2 yang mula dikesan pertengahan bulan Disember 2019 sehingga ke hari ini. Pandemik ini telah membawa kepada gangguan sosioekonomi secara global, penangguhan dan pembatalan acara kebudayaan, keagamaan dan kesukanan, serta ketakutan yang meluas dalam kekurangan bekalan. Gangguan sosioekonomi merangkumi aktiviti riadah dan rekreasi, pekerjaan dan perubahan kepada undang-undang. Pengawalan dan penambahan undang-undang yang ketat menyebabkan ramai yang menghadapi masalah kewangan dan sebahagian daripada mereka juga kehilangan pekerjaan. Walaupun pandemik ini telah membawa pelbagai kekangan dalam kehidupan masyarakat, namun, masyarakat yang seiring dengan globalisasi ini bijak mengambil peluang ke atas situasi yang dicipta oleh pandemik COVID-19 ini.

Ramai yang mengambil peluang untuk menjadi penghantar makanan (rider) bagi menampung keperluan seharian. Pekerjaan sebagai penghantar makanan dilihat seperti tidak penting dalam mata masyarakat terutamanya bagi golongan yang lebih tua. Namun realitinya, bekerja sebagai penghantar makanan bukan saja membantu seseorang individu itu untuk menampung keperluan diri, bahkan mampu menampung keperluan seisi keluarga sehingga ada yang sanggup melepaskan pekerjaan tetap untuk menjadi penghantar makanan. Hal ini kerana sepanjang pandemik ini, ramai yang takut untuk keluar rumah apatah lagi menjamu selera di kedai. Pembelian atas talian menjadi pilihan masyarakat kini kerana tidak perlu keluar rumah serta lebih selamat. Pekerja penghantar dilihat memainkan peranan penting dalam kehidupan masyarakat kini dan perkhidmatan yang disampaikan amat dihargai orang ramai sepanjang pandemik ini kerana telah membantu orang ramai dalam memenuhi keperluan diri serta menanggung risiko daripada terjangkitnya wabak penyakit korona virus ini. Selain menanggung risiko menjangkiti penyakit Covid-19, terdapat banyak lagi risiko serta kekangan yang dihadapi oleh pekerja penghantar makanan yang tidak diketahui oleh orang ramai. Oleh yang demikian, kajian ini dijalankan bagi melihat cabaran-cabaran yang dihadapi oleh para pekerja penghantar makanan (rider) semasa berlakunya pandemik Covid-19.

\section{Objektif}

Tujuan kajian terhadap cabaran perkhidmatan penghantaran makanan semasa pandemik COVID-19 ialah:

1) Mengenal pasti faktor jarak penghantaran mempengaruhi pekerjaan penghantaran semasa pandemik COVID-19.

2) Mengenal pasti faktor masa mempengaruhi pekerjaan penghantaran semasa pandemik COVID-19.

3) Mengenal pasti faktor caj penghantaran mempengaruhi pekerjaan penghantaran semasa pandemik COVID-19.

4) Mengenal pasti risiko pekerja penghantar lebih tinggi semasa pandemik COVID-19.

\section{Kajian Literatur}

Wabak COVID-19 ini yang tersebar pada tahun 2020 ini mempengaruhi semua aspek kehidupan dan membawa kepada berlakunya Perintah Kawalan Pergerakan (PKP). Semua individu tidak dibenarkan keluar rumah sesuka hati seperti kebiasaan. Oleh itu, perkhidmatan penghantaran makanan menjadi semakin meningkat. Menurut Hoffman et al. (2010), melabel barang sebagai objek, alat atau benda dan perkhidmatan sebagai tindakan, usaha atau persembahan. Menurut Pigatto et al. (2017), perkhidmatan penghantaran makanan dalam talian boleh disifatkan sebagai platform perniagaan yang menyediakan perkhidmatan pesanan, pembayaran dan pemantauan proses tetapi tidak bertanggungjawab dalam penyediaan makanan. Perkhidmatan penghantaran makanan dari restoran ke 
rumah pelanggan mengalami perubahan yang signifikan ketika platform baru dalam talian berlumba untuk menangkap pasar dan pelanggan di seluruh dunia.

Sebagai contoh syarikat yang mengeluarkan perkhidmatan penghantaran makanan ialah UberEats, Food Panda, Service Room, GrubHub, HungryNaki, PathaoFood dan banyak lagi. Menurut pembacaan juga, peneraju pasaran dalam runcit makanan dalam talian Jerman adalah HelloFresh edagang semata-mata, sebuah permulaan internet khusus. Mereka diikuti oleh bahagian makanan Amazon.de, dan REWE (Statistk, 2019). Pelaku baru ini menyumbang kepada pelbagai model perniagaan dan saluran pengedaran yang dapat membantu mengatasi halangan yang ada dan menyokong peralihan. Sekarang, dengan peningkatan digitalisasi yang disebabkan oleh COVID-19, kemungkinan runcit makanan dalam talian dapat bergerak ke fasa pertumbuhan baru, dengan era peruncitan makanan yang baru muncul. Era baru seperti ini dapat terwujud dalam rasi bintang pelaku baru, pembentukan model bisnis baru, daya tarik untuk segmen pelanggan baru dan penyebaran ruang e-runcit. Walau bagaimanapun, permintaan yang tinggi terhadap perkhidmatan penghantaran makanan tetapi masih terdapat pelbagai cabaran yang perlu dilalui oleh mereka. Setelah mendapat pesanan daripada pelanggan mereka pula perlu mengharungi pelbagai rintangan sebelum makanan tersebut sampai kepada pelanggan mereka. Pelbagai kerenah pelanggan yang terpaksa mereka hadap semasa melakukan kerja mereka. Oleh itu, terdapat beberapa cabaran yang dihadapi oleh pekerja penghantar makanan.

\section{Metod Kajian}

Kajian ini merupakan satu kajian deskriptif. Statistik deskriptif merujuk kepada maklumat dalam bentuk angka akan dikumpulkan, disusun, ditafsirkan dan dianalisis sebelum membuat kesimpulan dan keputusan penting dengan menggunakan ukuran kecenderungan memusat, frekuensi dan ukuran serakan. Kajian ini menggunakan format kajian kuantitatif dan borang soal selidik sebagai instrumen kajian. Borang soal selidik diedarkan secara atas talian kepada masyarakat setempat bagi mendapatkan data primer bagi menghasilkan analisis yang lebih tepat. Jumlah populasi dalam kajian ini ialah seramai 43 orang. Borang soal selidik terdiri daripada dua bahagian. Bahagian pertama iaitu demografi adalah untuk maklumat diri responden. Bahagian kedua pula ialah maklum balas kajian yang terdiri daripada empat bahagian iaitu yang pertama ialah faktor masa penghantaran. Kedua adalah faktor jarak penghantaran. Ketiga ialah caj penghantaran manakala bahagian keempat risiko kerugian semasa penghantaran makanan pada musim COVID-19. Skor skala pengukuran Likert digunakan untuk kajian ini berserta gabungan soalan subjektif bagi mendapatkan cadangan responden. Skor skala Likert yang digunakan dari 1 hingga 3 iaitu 1 setuju, 2 mungkin, 3 tidak setuju.

\section{Analisis Kajian}

\section{Analisis Demografi kajian}

Kajian ini memperlihatkan pandangan dan pendapat responden mengenai cabaran yang bakal dihadapi oleh pekerja penghantaran makanan sepanjang menghadapi pandemik COVID-19. Pandangan dan pendapat responden adalah berbeza berdasarkan latar belakang. Oleh itu,data mengenai latar belakang responden telah dikumpulkan semasa soal selidik dijalankan.
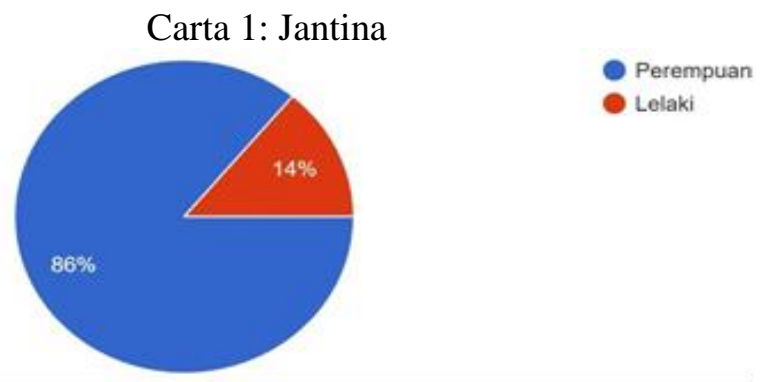
Carta 1 menunjukkan maklumat jantina responden seramai 43 orang yang terdiri daripada 37 orang responden perempuan $(86 \%)$ manakala 6 orang responden lelaki $(14 \%)$. Carta 2 menunjukkan maklumat umur responden. Responden yang berumur 21 sehingga 23 tahun adalah yang paling ramai iaitu 24 orang $(55.8 \%)$. Seramai 10 orang $(23.3 \%)$ responden berumur 24 hingga 26 tahun manakala 5 orang (11.6\%) berumur 27 hingga 29 tahun. Responden berumur 30 tahun dan ke atas adalah seramai 3 orang $(7 \%)$ dan 18 hingga 20 tahun adalah seorang $(2.3 \%)$.

\section{Carta 2 : Umur}

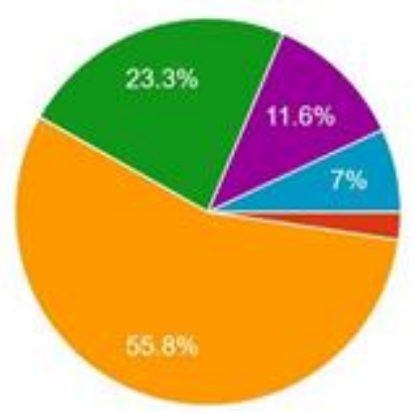

Carta 3 : Lokasi Penempatan

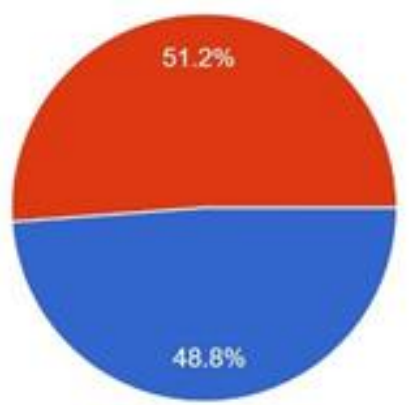

15-17 tahun

18-20 tahun

21-23 tahun

24-26 tahun

27-29 tahun

30 tahun dan keatas

Berdasarkan carta 3, terdapat sebanyak (51.2\%) responden iaitu 22 orang tinggal di luar bandar ketika PKP. 21 orang (48.8\%) responden lagi berada di bandar ketika PKP. Carta 4 mengandungi maklumat mengenai pengalaman bekerja sebagai seorang penghantar makanan di mana seramai 33 orang (76.7\%) tidak pernah bekerja, 6 orang (14\%) pernah bekerja dan 4 orang $(9.3 \%)$ pula sedang bekerja.

Carta 5 pula mengandungi maklumat mengenai kekerapan menggunakan perkhidmatan penghantaran makanan dalam kalangan responden. Kekerapan tertinggi adalah sebanyak sekali hingga dua kali (44.2\%). Kemudian, 5 hingga 6 kali ialah seramai 6 orang (14\%), 3 hingga 4 kali seramai 4 orang $(9.3 \%)$ serta 7 kali dan ke atas seramai 3 orang (7\%). Selebihnya, jawapan yang diberikan adalah lainlain sebanyak (25.5\%) iaitu kebanyakannya tidak pernah.

Carta 4: Status Pekerjaan Perkhidmatan Makanan

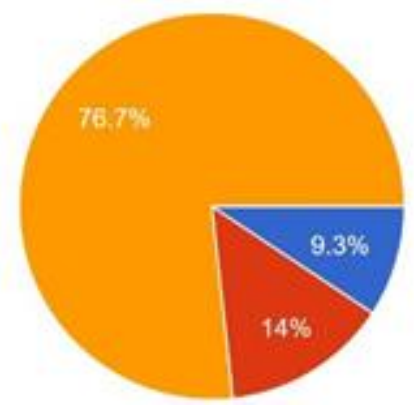


DOI: https://doi.org/10.47405/mjssh.v6i5.782

Carta 5 : Penggunaan Perkhidmatan Makanan
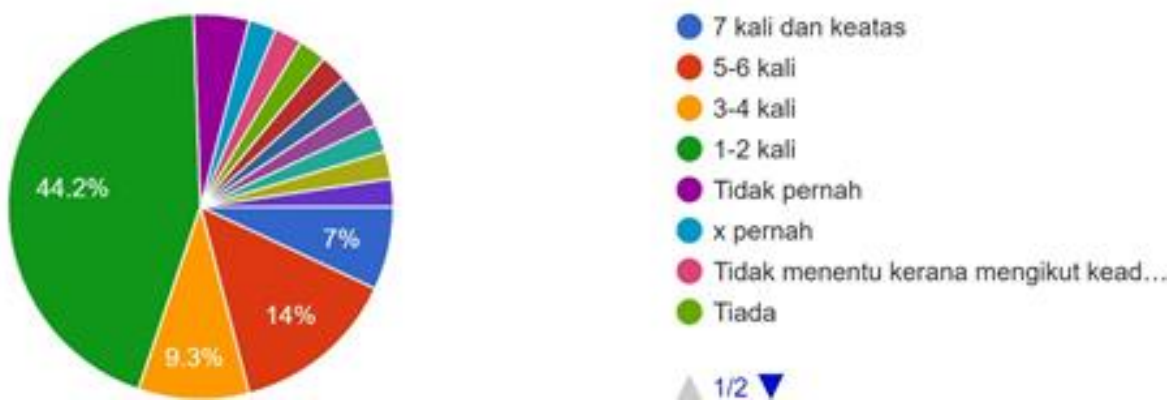

Carta 6 mengandungi maklumat responden tentang pengalaman menghadapi dalam menghadapi cabaran ketika menggunakan perkhidmatan penghantaran makanan. $65.1 \%$ iaitu 28 orang responden mengatakan mereka tidak pernah menghadapi masalah ketika menggunakan perkhidmatan makanan manakala 11 orang $(25.6 \%)$ responden mengatakan mereka pernah mengalami masalah ketika menggunakan perkhidmatan penghantaran makanan. 2 orang responden $(4.6 \%)$ mengatakan tidak pernah menggunakan perkhidmatan ini manakala selebihnya (4.6\%) kadangkala mengalami masalah ini.

Carta 6 : Kekerapan Penggunaan Perkhidmatan Makanan
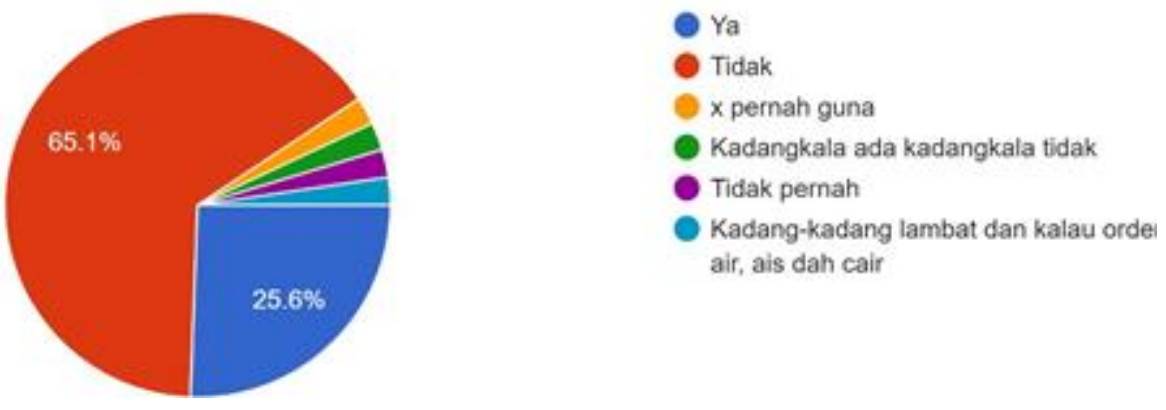

\section{Analisa Maklum Balas Masa Perkhidmatan Penghantaran Makanan}

Maklum balas ini terdiri daripada 4 bahagian, di mana ia dibahagikan kepada 4 cabaran utama yang dihadapi oleh pekerja-pekerja penghantaran makanan. Maklum balas ini juga mengandungi pendapat responden mengenai punca terjadinya masalah tersebut.

Berdasarkan carta 7, seramai 16 orang responden (37.2\%) bersetuju bahawa penyingkatan masa untuk perkhidmatan penghantaran makanan semasa pandemik memberi kesan buruk kepada pengguna manakala 15 orang (34.9\%) responden pula tidak bersetuju. Selebihnya, sebanyak 12 orang (27.9\%) ragu-ragu terhadap bahawa penyataan bahawa penyingkatan masa penghantaran memberi kesan buruk kepada pengguna.

Carta 7 Pandangan Responden Terhadap Penyingkatan Masa

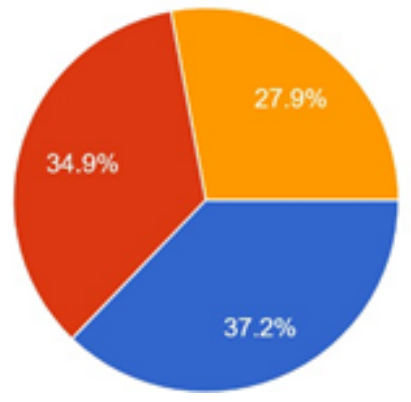

Setuju

Tidak Setuju

Mungkin 
Kajian ini juga mengandungi pendapat responden tentang kesan buruk yang dihadapi oleh pengguna apabila masa penghantaran terpaksa disingkatkan semasa PKP. Seramai 7 orang (16\%) responden menyatakan pembelian menjadi terhad dan 2 orang (4.6\%) menyatakan terdapat kawasan yang tidak dapat dihantar kerana jauh dan tidak sempat. 6 orang (13.9\%) responden seterusnya menyatakan penghantaran makanan lebih pantas kerana pekerja perlu mengejar waktu tamat bekerja.

Terdapat juga pendapat lain seperti 4orang (9.2) menyatakan pesanan lambat sampai kerana banyak permintaan dalam 1 masa serta 6 orang responden (13.9\%) tidak dapat membuat pesanan sesuka hati terutama pada waktu malam. Selain itu, 8 orang (18.6\%) responden tidak bersetuju bahawa penyingkatan masa memberi kesan, 1 jawapan (2.3\%) lain iaitu tidak pernah menggunakan perkhidmatan penghantaran makanan dan jawapan yang tidak berkaitan $(20.9 \%)$.

Jadual 1: Pandangan responden terhadap penyingkatan masa

\begin{tabular}{lcc}
\hline Kesan Buruk Kepada Pengguna & Kekerapan & Peratus (\%) \\
\hline Pembelian yang terhad & 7 & 16 \\
$\begin{array}{l}\text { Pesanan dihantar pantas } \\
\text { Terdapat kawasan yang tidak dapat dihantar }\end{array}$ & 6 & 13.9 \\
$\begin{array}{l}\text { Pesanan lambat sampai kerana banyak } \\
\text { permintaan dalam 1 masa }\end{array}$ & 4 & 4.6 \\
$\begin{array}{l}\text { Tidak dapat membuat pesanan sesuka hati } \\
\text { (contoh pada waktu malam) }\end{array}$ & 6 & 9.2 \\
$\begin{array}{l}\text { Tidak setuju bahawa penyingkatan masa } \\
\text { memberi kesan }\end{array}$ & 8 & 13.9 \\
\hline
\end{tabular}

Terdapat 28 orang $(65.1 \%)$ bersetuju bahawa penyingkatan masa memberi kesan kepada pekerja penghantaran makanan manakala 4 orang $(9.3 \%)$ tidak bersetuju. 11 orang $(25.6 \%)$ ragu-ragu tentang penyataan ini.

Carta 8: Pandangan mengenai penyingkatan masa penghantaran memberi kesan kepada pekerja penghantaran perkhidmatan makanan

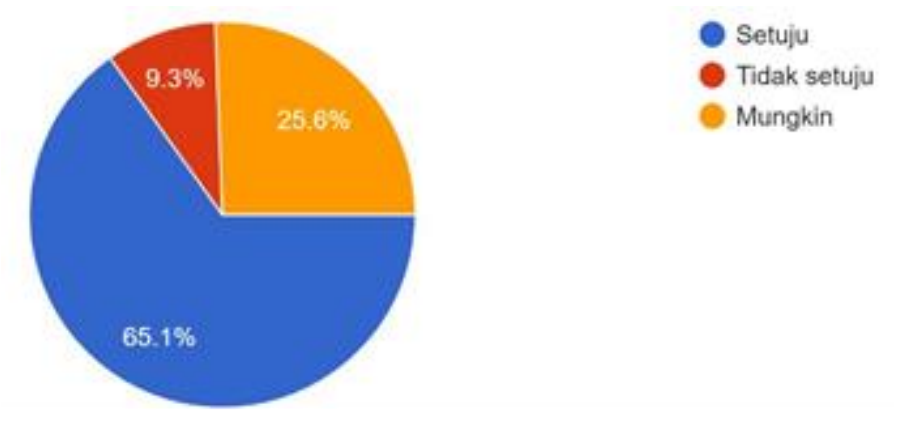

Berikut merupakan pandangan responden mengenai kesan buruk yang bakal berlaku kepada pekerja penghantaran makanan. Majoriti dengan 13 responden (30.2\%) menjawab pekerja tidak dapat menambah pendapatan kerana kurang penghantaran yang dibuat. Selain itu, terdapat responden lain seperti pekerja tidak menang tangan atau terkejar-kejar semasa membuat penghantaran dan pekerja menghadapi risiko bahaya serta masalah kesihatan dengan masing-masing dinyatakan oleh 7 orang (16.3\%) responden manakala tempahan bertindih dan pekerja menghadapi cabaran cuaca dinyatakan masing-masing sebanyak seorang (2.3\%). 2 orang (4.6\%) responden menyatakan bahawa pekerja bakal dimarahi oleh pelanggan dan 3 orang lagi (7\%) tidak menyokong penyataan bahawa penyingkatan masa memberi kesan buruk kepada pekerja penghantar makanan. Sebanyak 9 jawapan $(20.9 \%)$ tidak berkaitan dengan soalan. 
DOI: https://doi.org/10.47405/mjssh.v6i5.782

Jadual 2: Pandangan responden terhadap penyingkatan masa untuk perkhidmatan penghantaran makanan

\begin{tabular}{lcc}
$\begin{array}{l}\text { Penyingkatan Masa Memberi Kesan Buruk } \\
\text { Kepada Pekerja Penghantar Makanan }\end{array}$ & Kekerapan & Peratus (\%) \\
\hline $\begin{array}{l}\text { Tidak dapat menambah pendapatan lebih/ } \\
\text { pendapatan kurang }\end{array}$ & 13 & 30.2 \\
Tidak menang tangan/ terkejar-kejar & 7 & 16.3 \\
Risiko bahaya dan masalah kesihatan & 7 & 16.3 \\
Tempahan bertindih & 1 & 2.3 \\
Dimarahi pelanggan & 2 & 4.6 \\
Masalah cuaca/ hujan & 1 & 2.3 \\
Tidak menyokong penyingkatan masa memberi & 3 & 7.0 \\
kesan buruk kepada pekerja & & 20.9 \\
Tidak berkaitan & 9 & \\
\hline
\end{tabular}

\section{Analisa Maklum Balas Jarak Perkhidmatan Penghantaran Makanan}

Carta 9 menunjukkan pendapat responden terhadap pergerakan terhad mendatangkan masalah kepada pekerja penghantar makanan. 34 orang $(79.1 \%)$ bersetuju bahawa masalah bakal timbul kepada pekerja kerana pergerakan yang terhad manakala 4 lagi (9.3\%) tidak menyokong. Selebihnya 5 orang tidak pasti dengan penyataan berikut.

Carta 9: Pendapat terhadap pergerakan yang terhad menyebabkan kesukaran terhadap pekerja untuk melakukan perkhidmatan penghantaran makanan

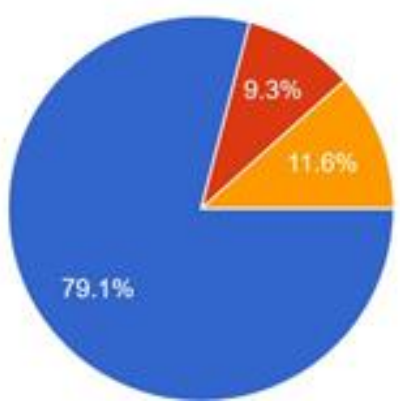

Jadual 3 menunjukkan pandangan responden terhadap pergerakan yang terhad menyebabkan kesukaran terhadap pekerja untuk melakukan perkhidmatan penghantaran makanan. Respons yang paling tinggi ialah terdapat rumah atau kawasan yang dapat dihantar makanan dengan 11 orang responden (25.6\%). Terdapat juga jawapan-jawapan yang lain seperti 4 orang (9.3\%) menjawab pesanan lambat sampai, 3 orang $(7 \%)$ menyatakan sukar mencari rumah atau jalan, 3 orang (7\%) pelanggan atau pendapatan kurang dan $5(11.6 \%)$ responden lagi menjawab jalan banyak tertutup atau banyak sekatan jalan raya. Terdapat juga jawapan yang tidak berkaitan sebanyak 9 jawapan iaitu 20.9\% manakala jawapan lain-lain sebanyak 8 jawapan (18.6\%).

Jadual 3: Pendapat terhadap pergerakan yang terhad menyebabkan kesukaran terhadap pekerja untuk melakukan perkhidmatan penghantaran makanan

\begin{tabular}{lcc}
\hline $\begin{array}{l}\text { Pergerakan yang terhad menyebabkan } \\
\text { kesukaran terhadap pekerja penghantaran makanan }\end{array}$ & Kekerapan & Peratus (\%) \\
\hline Pesanan lambat sampai & 4 & 9.3 \\
Sukar mencari rumah/ jalan & 3 & 7 \\
Pelanggan/ pendapatan kurang & 3 & 7 \\
\hline
\end{tabular}


DOI: https://doi.org/10.47405/mjssh.v6i5.782

\begin{tabular}{lcc}
\hline Jalan tertutup/ banyak sekatan & 5 & 11.6 \\
Rumah yang jauh tidak dapat membuat pesanan/ Tidak dapat & 11 & 25.6 \\
mengunjung sesetengah kawasan & & \\
Tiada jawapan & 9 & 20.9 \\
Lain-lain & 8 & 18.6 \\
\hline
\end{tabular}

Carta 10 pula mengandungi pendapat responden mengenai pendudukan di luar bandar mendapat impak yang teruk berbanding kawasan bandar dalam mendapatkan perkhidmatan penghantaran makanan. 27 orang $(62.8 \%)$ bersetuju, 8 orang $(18.6 \%)$ tidak bersetuju manakala $8(18.6 \%)$ orang lagi natural.

Carta 10: Penduduk di kawasan luar bandar terutamanya mendapatkan impak buruk akibat pandemik covid-19
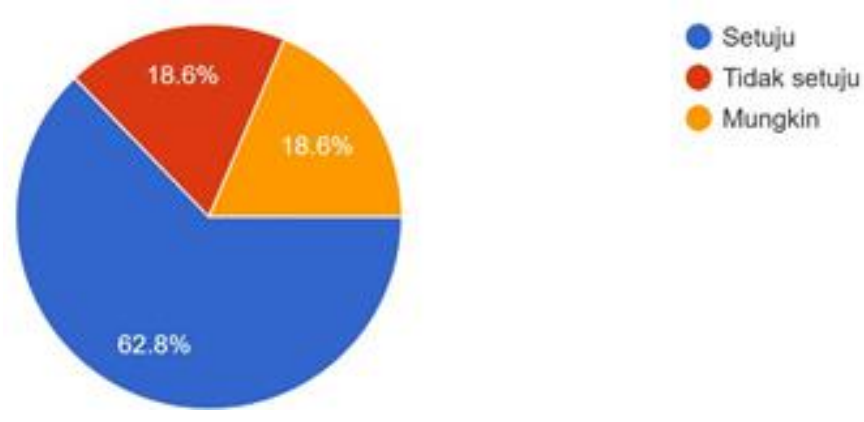

Jadual 4 menunjukkan pendapat responden mengenai penyataan penduduk di kawasan luar bandar mendapat impak yang buruk dalam penggunaan perkhidmatan makanan ini. Seramai 17 orang (39.5\%) menyatakan bahawa kerana pekerja tidak memasuki kawasan luar bandar atau pergerakan terhad. 9 (20.9\%) orang menyatakan penduduk luar bandar tidak memerlukan perkhidmatan ini, 6 (14\%) orang menyatakan sukar mendapatkan bekalan makanan kurang atau bahan mentah, dan 1 (2.3\%) orang menyatakan penduduk di luar bandar tiada kesan. Lain-lain jawapan sebanyak 4 (9.2\%) orang dan 6 $(14 \%)$ lagi tiada jawapan.

Jadual 4: Impak kepada penduduk luar bandar

\begin{tabular}{lcc}
\hline $\begin{array}{l}\text { Penduduk Di Kawasan Luar Bandar Terutamanya } \\
\text { Mendapatkan Impak Buruk Akibat Pandemik }\end{array}$ & Kekerapan & Peratus (\%) \\
\hline Tiada jawapan & 6 & 14 \\
Pekerja tidak memasuki kawasan luar bandar/ pergerakan terhad & 17 & 39.5 \\
penduduk luar bandar tidak memerlukan perkhidmatan ini & 9 & 20.9 \\
Sukar mendapatkan bekalan makanan kurang/ bahan mentah & 6 & 14 \\
Tidak terkesan & 1 & 2.3 \\
Lain-lain & 4 & 9.2 \\
\hline
\end{tabular}

\section{Analisa Maklum Balas Caj Penghantaran Makanan}

Carta 11 mengumpul maklumat mengenai pendapat responden tentang Caj penghantaran yang dikenakan mahal menyebabkan pelanggan tidak/kurang menggunakan perkhidmatan penghantaran makanan. Seramai 55.8\% menyokong penyataan ini manakala 9 orang $(20.9 \%)$ tidak bersetuju. 10 orang pula $(23.3 \%)$ ragu-ragu. Carta 12 mengandungi pendapat caj penghantaran yang dikenakan bergantung kepada jarak penghantaran menyebabkan rider menanggung kemarahan pengguna dimana 22 responden $(51.2 \%)$ bersetuju, 11 orang (25.6\%) tidak bersetuju dan 10 orang (23.3\%) ragu-ragu. 
DOI: https://doi.org/10.47405/mjssh.v6i5.782

Carta 11: Caj penghantaran

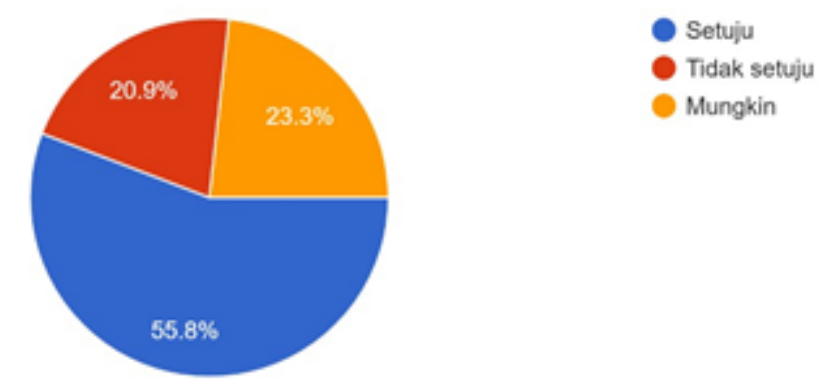

Carta 12: Maklumat caj penghantaran

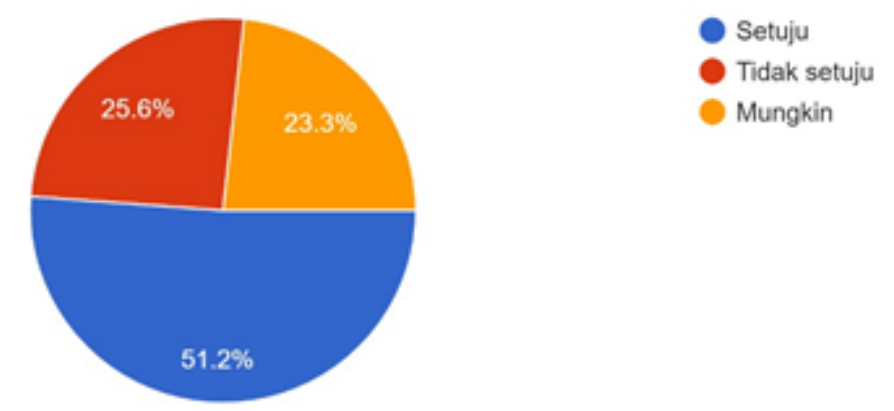

\section{Analisa Maklum Balas Caj Penghantaran Makanan}

Carta 13 menunjukkan pendapat kerugian bakal dialami oleh pekerja penghantar makanan adalah tinggi berbanding pelanggan. 25 orang responden $(58.1 \%)$ bersetuju, 3 orang $(7 \%)$ tidak bersetuju dan 15 responden $(34.9 \%)$ kurang pasti. Jadual 5 menyatakan pendapat responden mengenai risiko kerugian yang bakal dikenakan kepada rider. 10 responden (23\%) menyatakan bahawa pelanggan bakal membatalkan pesanan menyebabkan rider menanggung rugi. 3 respons (6.9\%) lain adalah kurang pendapatan kerana kurang permintaan perkhidmatan, 4 respons $(9.2 \%)$ adalah rider perlu untuk menanggung kos barang rosak seperti membaiki motor ataupun jika berlaku kemalangan dan 4 lagi $(9.2 \%)$ menyatakan bahawa pelanggan tidak membuat bayaran ataupun masalah-masalah yang mungkin ditimbulkan oleh pelanggan. 1 (2.3\%) respons menyatakan bahawa rider bakal berdepan masalah cuaca seperti hujan. Terdapat juga (18.4\%) jawapan bahwa mereka tidak pasti dan jawapan lain. Ada juga tiada jawapan (16.1\%).

Carta 13: Risiko kerugian bakal dialami oleh rider adalah tinggi berbanding pelanggan

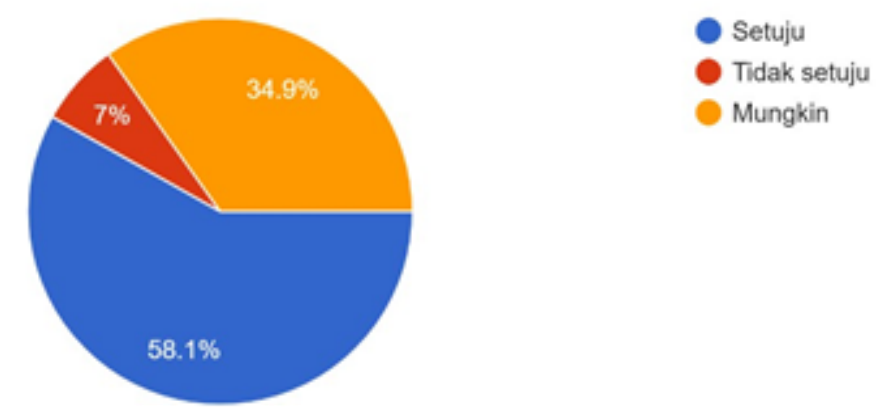

Jadual 5 Pendapat Mengenai Risiko Kerugian Kepada Rider

\begin{tabular}{lcc}
\hline Pendapat Mengenai Risiko Kerugian Kepada Rider & Kekerapan & Peratus (\%) \\
\hline Tiada jawapan & 7 & 16.1 \\
Tidak pasti & 8 & 18.4 \\
\hline
\end{tabular}


DOI: https://doi.org/10.47405/mjssh.v6i5.782

\begin{tabular}{lcc}
\hline Lain-lain & 6 & 13.8 \\
Kurang pendapatan kerana kurang permintaan & 3 & 6.9 \\
Menanggung kos barang rosak/ baiki motor/ kemalangan & 4 & 9.2 \\
Pelanggan membatalkan pesanan & 10 & 23 \\
Pelanggan tidak membuat bayaran/ masalah dilakukan oleh & 4 & 9.2 \\
pelanggan & & \\
Berdepan masalah cuaca & 1 & 2.3 \\
\hline
\end{tabular}

\section{Perbincangan}

Antara cabaran yang dihadapi oleh mereka ialah jarak penghantaran adalah terhad, masa penghantaran makanan juga dihadkan, risiko rugi kepada pekerja penghantar makanan dan caj penghantaran mahal. Para pekerja tersebut telah dihadkan jarak penghantaran makanan sepanjang PKP ini berlangsung. Para pekerja akan ditangkap apabila pekerja gagal mengemukakan dua dokumen penting itu dan terbukti lokasi pelanggan melebihi 10km dari rumah. Menurut ketua polis di Terengganu (Chik, 2020) menyatakan bahawa tindakan tegas dan keras tanpa sebarang kompromi itu dilakukan berikutan masih ada yang sengaja melanggar syarat PKP dengan membuat penghantaran makanan melebihi jarak perjalanan dibenarkan. Selain itu, masa penghantaran makanan juga dihadkan merupakan cabaran kepada pekerja penghantar makanan. Para pekerja penghantar makanan pada mulanya boleh menghantar makanan lebih lama tetapi kini mereka hanya dapat menghantar makanan daripada pukul 8 pagi sehingga pukul 8 malam sahaja bermula pada 1 April 2020. Peluang mereka untuk mendapatkan duit lebih sudah disekat. Mereka hanya dibenarkan membuat penghantaran pesanan pada masa yang ditetapkan sahaja. Jika mereka ingkar, mereka akan dikenakan tindakan oleh pihak yang berkuasa.

Seterusnya, para penghantar makanan mempunyai risiko yang tinggi untuk mengalami kerugian. Pekerja terpaksa menanggung kerugian apabila pelanggan yang memesan makanan hanya untuk mempermainkan mereka. Menurut artikel (MStar, 2020) menyatakan bahawa pekerja menanggung rugi apabila pelanggan hanya meletakkan alamat yang salah ataupun hanya untuk mengenakan pekerja penghantaran makanan itu sendiri. Menurut posting yang dimuat naik di Facebook Zulhairy, penghantar makanan tersebut mencari-cari alamat yang diberikan oleh pelanggan dengan meletakkan alamat 'rumah aku' dan kemudiannya membatalkan pesanan dengan hanya menyatakan mereka masih belum bayar. Jadi mereka boleh membatalkan sesuka hati mereka sahaja. Menurut keratan akhbar MStar yang dikarang oleh Fiqrie, terdapat keluhan daripada 'rider' apabila pelanggan terpaksa membatalkan pesanan makanan selepas makanan setelah selesai dibeli. Hal ini sangat memberi kerugian kepada 'rider' kerana terpaksa menghabiskan wang mereka untuk membeli pesanan pelanggan malah dibatalkan setelah pesanan tersebut dibeli oleh pekerja penghantar makanan tersebut.

Akhir sekali, caj perkhidmatan penghantaran makanan terlalu mahal merupakan salah satu cabaran bagi penghantar makanan. Menurut artikel AmazingNara, penghantar makanan telah dituduh tamak dan nak cepat kaya akibat mengambil caj penghantaran makanan terlampau mahal. Menurut artikel tersebut, pelanggan merasa terkilan kerana caj yang dikenakan sehingga RM10. Penghantar makanan terpaksa menanggung tohmahan tersebut. Pekerja tersebut sudah pasti akan menanggung malu dengan masyarakat sekeliling. Pekerja penghantaran makanan yang lain pasti akan terkena tempiasnya.

\section{Kesimpulan}

Kesimpulannya, terdapat pelbagai cabaran yang dihadapi oleh penghantar makanan 'rider' sepanjang tempoh Perintah Kawalan Pergerakan (PKP) akibat berlakunya kes COVID-19. Terdapat pelbagai cabaran yang dihadapi oleh pekerja penghantar makanan semasa pandemik COVID-19 ini melanda. Antara cabaran yang dihadapi oleh mereka ialah jarak penghantaran adalah terhad, masa penghantaran makanan juga dihadkan, risiko rugi kepada pekerja penghantar makanan dan caj penghantaran mahal. Para pekerja tersebut telah dihadkan jarak penghantaran makanan sepanjang PKP ini berlangsung. 
Para pekerja akan ditangkap apabila pekerja gagal mengemukakan dua dokumen penting itu dan terbukti lokasi pelanggan melebihi $10 \mathrm{~km}$ dari rumah. Selain itu, masa penghantaran makanan juga dihadkan merupakan cabaran kepada pekerja penghantar makanan. Para pekerja penghantar makanan pada mulanya boleh menghantar makanan lebih lama tetapi kini mereka hanya dapat menghantar makanan daripada pukul 8 pagi sehingga pukul 8 malam sahaja bermula pada 1 April 2020 .

\section{Rujukan}

Agriculture, food, drinks and tobacco. (2009). Monthly Digest of Statistics, 761(1), 42-48. doi:10.1057/mds.2009.90

Fiqrie Firoz. (2020, 31 Mac). Pelanggan Batal Tempahan, Rider Foodpanda Terdetik. Diambil daripada https://www.mstar.com.my/lokal/viral/2020/03/31/food-panda-cancel-last-min

Innanie Arifin. (2019, 8 Nov). Cara Dapatkan Money Refund Dari Food Panda. Diambil daripada http://www.coklateyes.my/2019/11/cara-dapatkan-money-refund-dari-food.html

Kamarudin, H. (2020, 22 Mac). Covid-19: Penghantar makanan sanggup 'berlapar'. Diambil daripada https://www.sinarharian.com.my/article/74972/EDISI/Kelantan/Covid-19-Pengha ntar-makanansanggup-berlapar

Noorazura Abdul Rahman. (2020, 15 September). Rezeki 'Runner' Jatuh Haram Jika. Diambil daripada https://www.hmetro.com.my/mutakhir/2020/09/620888/rezeki-runner-jatuh-hara m-jika

Nora Mahpar. (2019, 4 April). Honestbee Lancar Perkhidmatan Penghantaran Makanan Halal. Diambil daripada https://www.bharian.com.my/bisnes/korporat/2019/04/548807/honestbeelancar- perkhidmatan-penghantaran-makanan-halal

Mohd Izzat. (2020, 9 April). Duduk Rumah, Pesan Online, Kami Hantar Order!. Diambil daripada https://www.mstar.com.my/travel/selera/2020/04/09/senarai-kedai-khidmat-peng hantaranmakanan

Mohd Nasir Sulaiman. (2020, 18 May). Khidmat Hantar Makanan Perlu Miliki Sijil Halal. Diambil daripada https://ansarcomp.com.my/index.php/2020/05/18/khidmat-hantar-makanan-perlumiliki-sijil-halal/

Raja Noraina. (2020, 21 Mei). Kek RM40, Caj Hantar RM38! . Diambil daripada https://www. hmetro.com.my/utama/2020/05/581012/kek-rm40-caj-hantar-rm38

Saad, A. T. (2020). Factors affecting online food delivery service in Bangladesh: an empirical study. British Food Journal, 123(2), 535-550. doi:10.1108/bfj-05-2020-0449

Shuhaniza Said. (2020, $30 \mathrm{Mac}$ ). Rancang pesanan online, tempoh hantar makanan berakhir 8 malam mulai 1 April. Diambil daripada https://www.mstar.com.my/lokal/semasa/2020/03/30/ehailingdan-teksi

Tina Bellon, A.. (2021). Uber Rides Take COVID-19 Hit But Food-Delivery Business Doubles. [online] U.S. Available at: https://www.reuters.com/article/us-uber-results/uber-rides-take-covid19-hit-but-f ood-delivery-business-doubles-idUSKCN25230

Utusan Borneo. Waktu operasi perniagaan 8 pagi - 8 malam bermula 1 April. (2020, $30 \mathrm{Mac})$. Diambil daripada https://www.utusanborneo.com.my/2020/03/30/pkp-waktu-operasi-perniagaan8- pagi-8-malam-bermula-1-april-1

Zaid Salim. (2020, 15 April). Hantar makanan lebih 10km tanpa bukti boleh ditangkap. Diambil daripada https://www.hmetro.com.my/mutakhir/2020/04/566996/hantar-makanan-lebih-10 kmtanpa-bukti-boleh-ditangkap

Zufazlin Baharuddin. (2020, 4 April). Cabaran pengendali F\&B semasa PKP bagi teruskan perniagaan. Diambil daripada https://bernama.com/bm/am/news_covid-19.php?id=1828489 